$1-1-1965$

\title{
Retailing horticultural specialties marketed as side- line products in West Virginia
}

Ronnie L. Burke

Robert L. Jack

Follow this and additional works at: https://researchrepository.wvu.edu/ wv_agricultural_and_forestry_experiment_station_bulletins

\section{Digital Commons Citation}

Burke, Ronnie L. and Jack, Robert L., "Retailing horticultural specialties marketed as side-line products in West Virginia" (1965). West Virginia Agricultural and Forestry Experiment Station Bulletins. 512.

https://researchrepository.wvu.edu/wv_agricultural_and_forestry_experiment_station_bulletins/476 @ WVU. It has been accepted for inclusion in West Virginia Agricultural and Forestry Experiment Station Bulletins by an authorized administrator of The Research Repository @ WVU. For more information, please contact ian.harmon@mail.wvu.edu. 


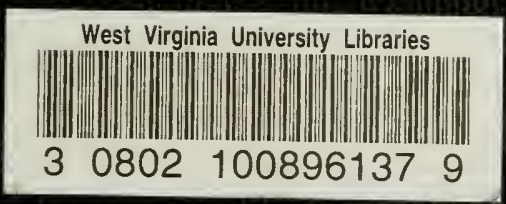


Digitized by the Internet Archive in 2010 with funding from Lyrasis Members and Sloan Foundation 


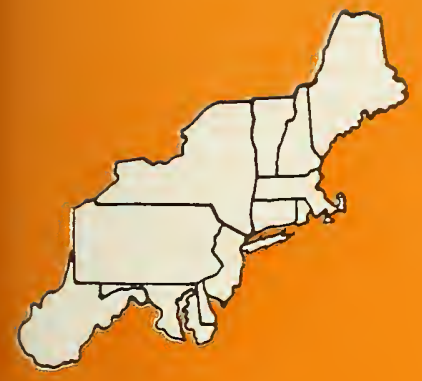

ETAILING

IORTICULTURAL SPECIALTIES

IARKETED AS SIDE-LINE PRODUCTS

W WEST VIRGINIA

Vest Virginia University gricultural Experiment Station ulletin 512 June 1965 



\section{Contents}

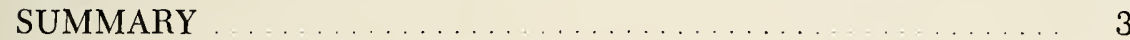

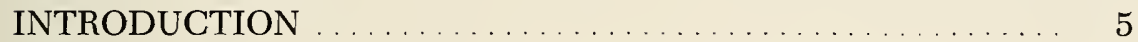

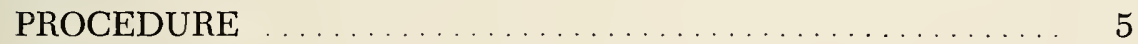

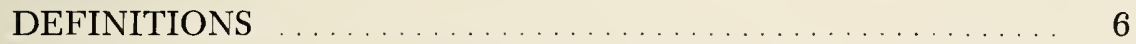

FINDINGS AND ANALYSIS . . . . . . . . . . . . . 6

Number and Location of Outlets $\ldots \ldots \ldots \ldots \ldots \ldots \ldots$

Types and Volumes of Products Marketed ............ 8

Procurement Sources ........................ 12

Number of Months of Sales ...................... 15

Sales Value ................................ 17

Consignment Sales ........................... 18

APPENDIX ................................. 21 


\section{THE AUTHORS}

Ronnie L. Burke is Research Assistant and Robert L. Jack is Assistant Agricultural Economist in the West Virginia University Agricultural Experiment Station.

\section{AC.KNOWLEDGMENT}

Special acknowledgment is due Roger Wr. Pease retired Assistant Agricultural Economist in the W'est Virginia University Agricultural Experiment Station. Mr. Pease prepared the schedules and supervised collection of the data.

This bulletin is published as a contribution to the Northeast Regional Marketing Research Project (NEM-S). The West Virginia research basic to the data included was supported by both state and resional research funds.

West Virginia University Agricultural Experiment Station

College of Agriculture, Forestry, and Home Economics

A. H. VanLandingham, Director

MORGANTOWN 


\section{Summary}

The purpose of this study was to determine the marketing practices and policies of retail outlets in West Virginia which market horticultural specialties as side-line products.

Data were obtained by personal interviews with 352 owners or operators of retail outlets which market horticultural specialties as sideline products in West Virginia. Thirty-three of the outlets were nurseries, 69 were florists, and 250 were mass outlets. Mass outlets included 110 grocery stores, 56 part-time ventures, 41 feed and farm supply stores, and 43 miscellaneous outlets. Products considered as side-line horticultural specialties were trees and shrubs, rose plants, bedding plants, vegetable plants, potted house plants, and cut flowers.

Retail outlets which market horticultural specialties as side-line products tend to locate in or around metropolitan areas of the State. The number of total retail outlets in a county is directly related to county population, county seat population, and population density per square mile. However, the number of mass outlets is influenced more by these population variables than are the number of nurseries and florists.

Although most retail outlets market some quantity of each side-line horticultural specialty, certain tendencies were found. First, there was a tendency for florists and mass outlets, and nurseries and mass outlets not to market the main-line products of the nurseries and florists, respectively. Second, florists specialize in marketing bedding plants as sideline horticultural specialties, while mass outlets specialize in vegetable plants and cut flowers. Nurseries tend to diversify by marketing a small volume of each horticultural specialty as a side-line product.

The major procurement sources of all outlets included in the study were in-State suppliers. However, considerable variation was found for different types of retail outlets and different types of products. Nurseries and florists produce most of their own side-line horticultural specialties, while mass outlets depend primarily on in-State suppliers. Rose plants were the only product which was procured primarily from out-of-State supply sources. Trees and shrubs were the only products which florists did not produce themselves, but depended primarily on in-State suppliers.

The number of months that horticultural specialties were marketed as side-line products showed considerable variation. The marketing period was relatively short, one to four months, for all side-line horticultural products, except cut flowers. Cut flowers were marketed primarily from five to twelve months during the year. Nurseries and mass outlets marketed their products one or two months, primarily. Florists' marketing period was usually three or four months. 
The average annual sales value of all retail outlets marketing horticultural specialties as side-line products was $\$ 1,666.37$. The average sales value was $\$ 2,347.62$ for nurseries, $\$ 3,017.50$ for florists and $\$ 1,242.48$ for mass outlets.

Consignment sales play only a minor role in the marketing of horticultural specialties as side-line products. The retailers of these products are influenced by suppliers of consigned side-line horticultural specialties. Suppliers control payment, disposal, and delivery methods of the consigned products. 


\title{
Retailing Horticultural Specialties Marketed As Side-Line Products In West Virginia
}

\author{
RONNIE L. BURKE and ROBERT L. JACK
}

Horticultural specialty wholesale value increased $\$ 649,525$ in West Virginia from 1949 to $1959 .{ }^{1}$ West Virginia's nursery-crop sales alone increased 173 per cent, compared with total farm-product sales which increased only 10 per cent. ${ }^{2}$ This increase in horticultural specialty sales can be attributed partially to higher incomes, more leisure time, newhome construction, and education of the consumer.

There also has been an increase in the number of retail outlets marketing horticultural specialties. It is expected that the increase in number of outlets has led to competition among retail outlets. Nurserymen and florists have been concerned about the competition and the portion of the increasing market that is being acquired by retail mass outlets."

The purpose of this study was to determine the marketing practices and policies of retail outlets (nurseries, florists, and mass outlets) marketing horticultural specialties as side-line products. The objectives were: (1) to determine the effect of population on the location of outlets narketing horticultural specialties as side-line products, (2) to determine the sales value and volume of horticultural specialties marketed as ide-line products by nurseries, florists, and mass outlets, (3) to investizate the extent of consignment sales of horticultural specialties marketed is side-line products by the retail outlets, and (4) to identify and evalute marketing practices and policies found by the study.

\section{Procedure}

A list of the names and addresses of retail outlets marketing hortiultural specialties as side-line products was prepared. This list included Il retail outlets in West Virginia except those in Gilmer, Jefferson, Aason, Mingo, Pocahontas, and Wirt counties. A 75 per cent random ample of these outlets was selected from this list. The sample included 3 nurseries, 69 florists, and 250 mass outlets. With the aid of a prepared chedule, personal interviews were conducted by enumerators with the wners or operators of the retail outlets selected.

${ }^{1}$ U.S. Bureau of Census. U.S. Census of Agriculture: 1959. Volume V. Special Reports, art I - Horticultural Specialties, (Washington: Government Printing Office, 1962), pp. 51-52. 2Roger W. Pease, Part-time Nurseries and The Market for Ornamental Trees and Shrubs,

gr. Exp. Sta., West Virginia University, Circular 110, August 1960.
'For definitions see page 6. 


\section{Definitions}

Florist: A retail outlet which acquired 66 per cent or more of its total retail sales volume from flower arrangements and whose main-line products were cut flowers and potted house plants. Horticultural specialties considered as side-line products were trees and shrubs, rose plants, bedding plants, and regetable plants.

Mass outlet: A retail outlet, such as grocery store or feed and farm supply store, which was non-nursery, non-florist and was not a branch of a chain store organization. Side-line horticultural specialty products were trees and shrubs, rose plants, bedding plants, vegetable plants, potted house plants, and cut flowers.

Miscellaneous outlet: A type of mass outlet which included stores and organizations which marketed horticultural specialties as side-line products. This type of mass outlet included department stores, hardware stores, novelty stores, vocational agriculture departments, etc.

Nursery: A retail outlet which produced at least 66 per cent of the total products sold on the retail market and whose mainline products were trees and shrubs. Side-line horticultural specialties were rose plants, bedding plants, vegetable plants, potted house plants, and cut flowers.

Side-line horticultural specialty: Plant or plants marketed by retail outlets in addition to main-line products. Considered as side-line horticultural specialties products in this study were trees and shrubs, rose plants, bedding plants, vegetable plants, potted house plants, and cut flowers. Main-line products of nurseries were trees and shrubs. Main-line products of florists were potted house plants and cut flowers. All of the horticultural specialties were considered as side-line products for the mass outlets.

\section{Findings and Analysis}

\section{Number and Location of Outlets}

The study included 352 retail outlets that marketed one or more horticultural specialties as side-line products. The outlets included 33 nurseries, 69 florists, and 250 mass outlets. The mass outlet group was composed of 110 grocery stores, 56 part-time greenhouse-florists and private ventures, 41 feed and farm supply stores, and 43 miscellaneous outlets (Table 1 ).

The nurseries tended to locate in or around the metropolitan areas of the State, and in counties with a relatively large population (Figure 1). Florists also tended to locate in or around metropolitan areas but were distributed more uniformly throughout the State than nurseries (Figure 2). Mass outlets also tended to concentrate in or around metropolitan areas but the concentration was not as great as for nurseries and florists (Figure 3). 


\section{TABLE 1}

Type, Number, and Percentage of Retail Outlets Which Sell Horticultural Specialties as Side-Line Products

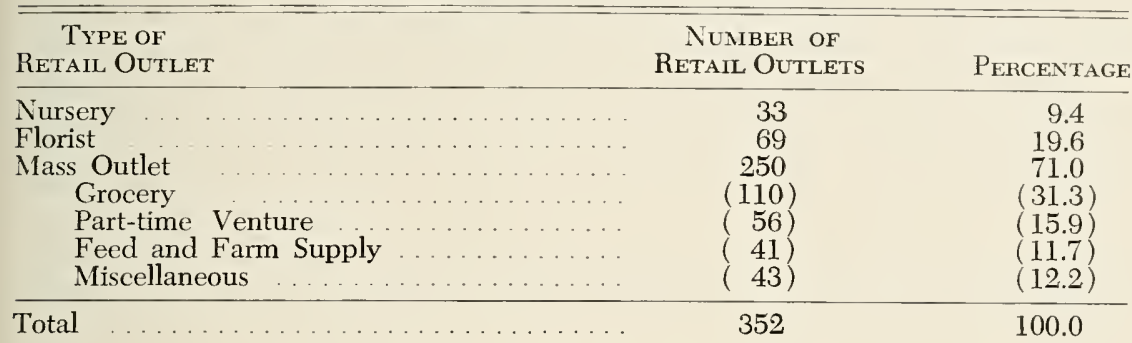

The concentration of the retail outlets in or around metropolitan areas is an indication that population is an important factor considered in the location of a retail outlet marketing horticultural specialties as side-line products.

One hundred and seventeen, or a third, of the total retail outlets which marketed horticultural specialties as side-line products were

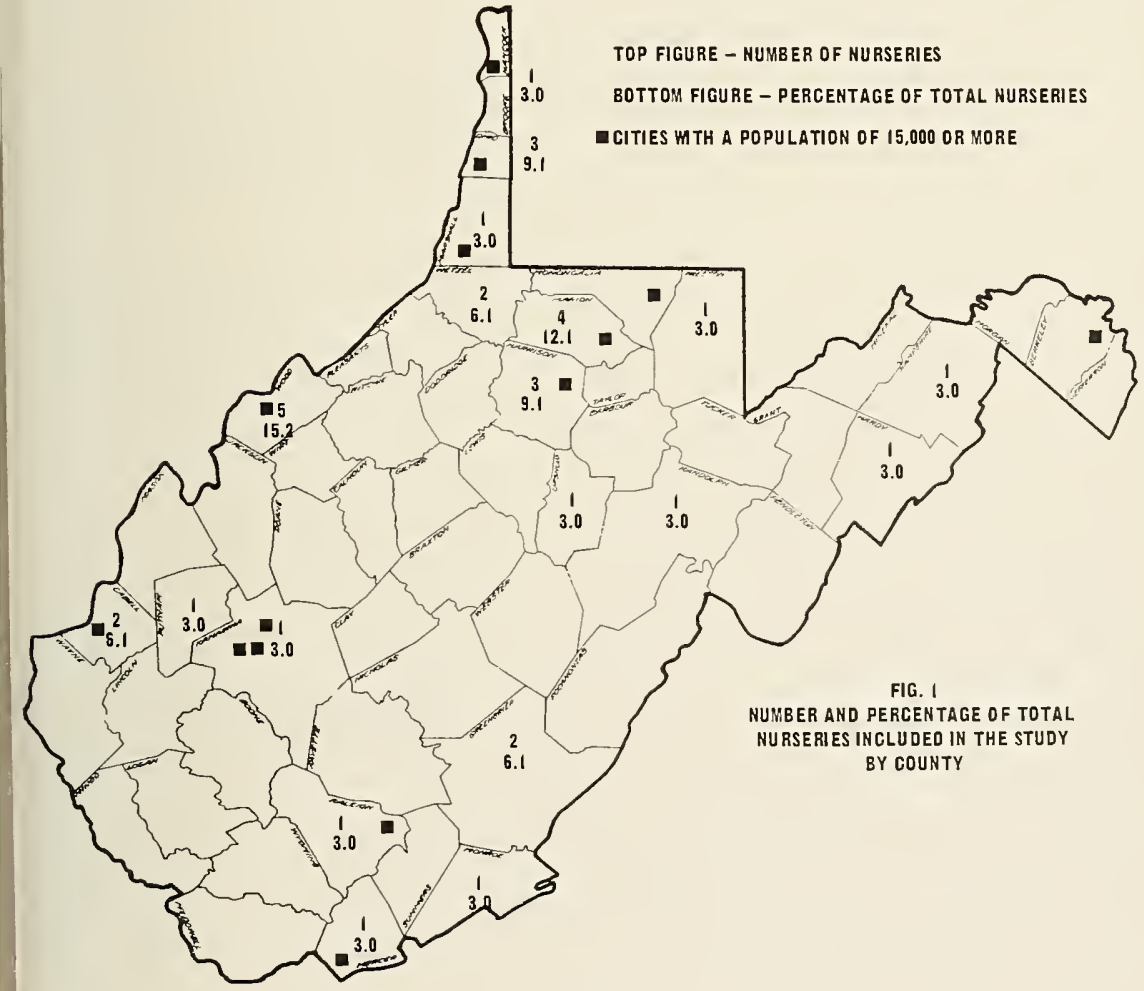


located in Marion, Harrison, Kanawha, Wood, Mercer, and Cabell counties. In 1960 these six counties had an average county population of 10S,206 persons, average county seat population of 46,367 persons, and an average population per square mile of 239.2 persons. On the other hand, Brooke, Fayette, Putnam, and Summer counties had only one retail outlet per county which marketed horticultural specialties as side-line products. The population of the county, the county seat population, and the county population per square mile for these four counties averaged $32,465,3,219$, and 132.5, respectively. These data suggest that a positive relationship exists between population and the number of retail outlets marketing horticultural specialties as side-line products (Appendix Table 1).

\section{Types and Volumes of Products Marketed}

The types and volumes of horticultural specialties marketed as sideline products varied considerably with the different types of retail outlets.

Of the 352 outlets, over three-fourths marketed vegetable plants, half marketed bedding plants, a third marketed potted house plants, and a fourth marketed rose plants as side-line products. Trees and shrubs were

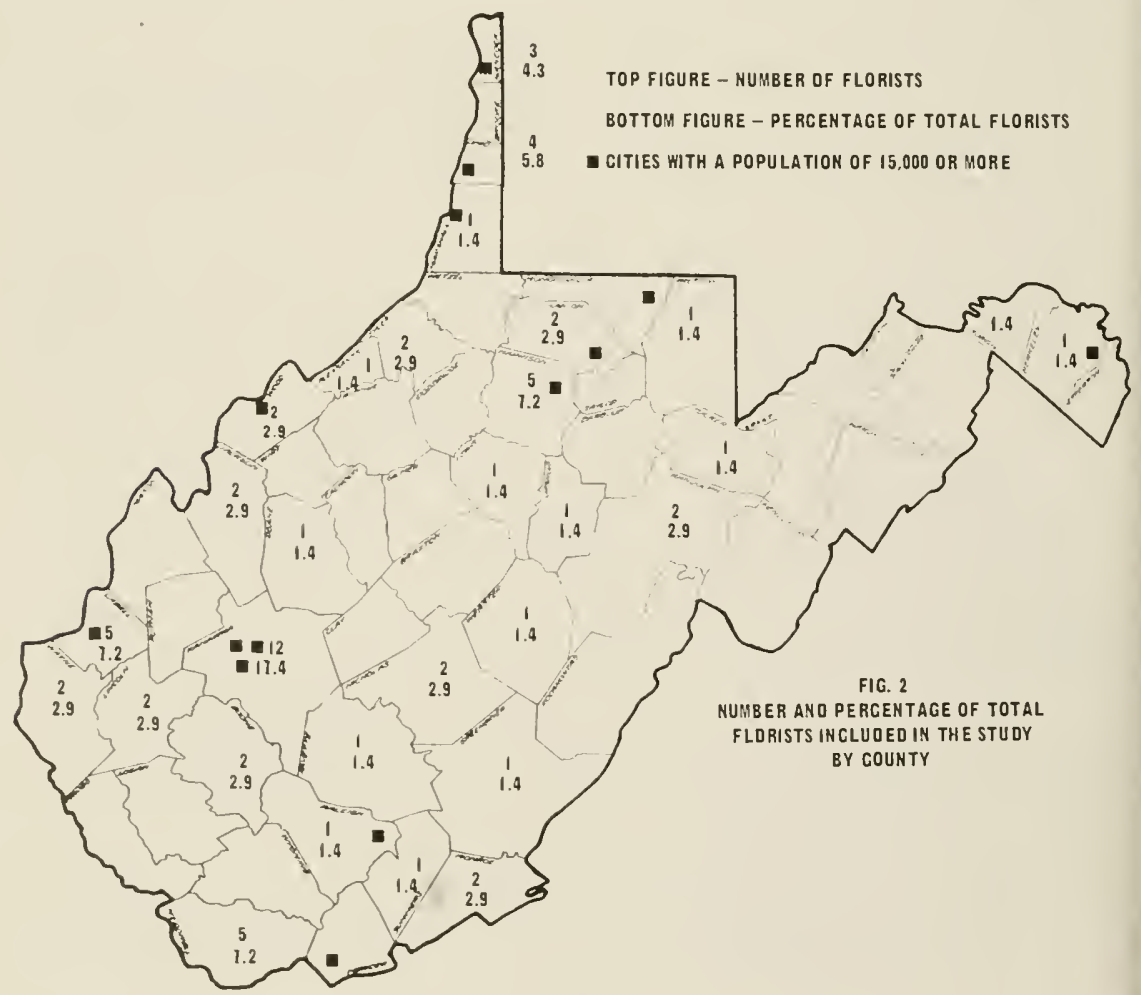


marketed by only 16 per cent of the total retail outlets (Table 2 ).

Most nurseries marketed bedding plants as a side-line product. Rose plants, vegetable plants, and potted house plants were also popular products. Only a relative few nurseries marketed cut flowers.

A major portion of the florists, 90 per cent, marketed bedding plants as a side-line product. Both rose and vegetable plants were marketed by two-thirds of the florists. A relatively small portion, 40 per cent, marketed trees and shrubs.

Eighty-four per cent of the mass outlets marketed vegetable plants as a side-line product. Almost half of the mass outlets marketed potted house plants and slightly more than a third marketed bedding plants. Around 10 per cent of the mass outlets marketed cut flowers and rose plants and 16 per cent marketed trees and shrubs.

These data indicate that most nurseries and florists marketed bedding plants, but most mass outlets marketed vegetable plants. Most of the nurseries did not market cut flowers and most of the florists did not market trees and shrubs. Most of the mass outlets did not market rose plants, cut flowers, or trees and shrubs.

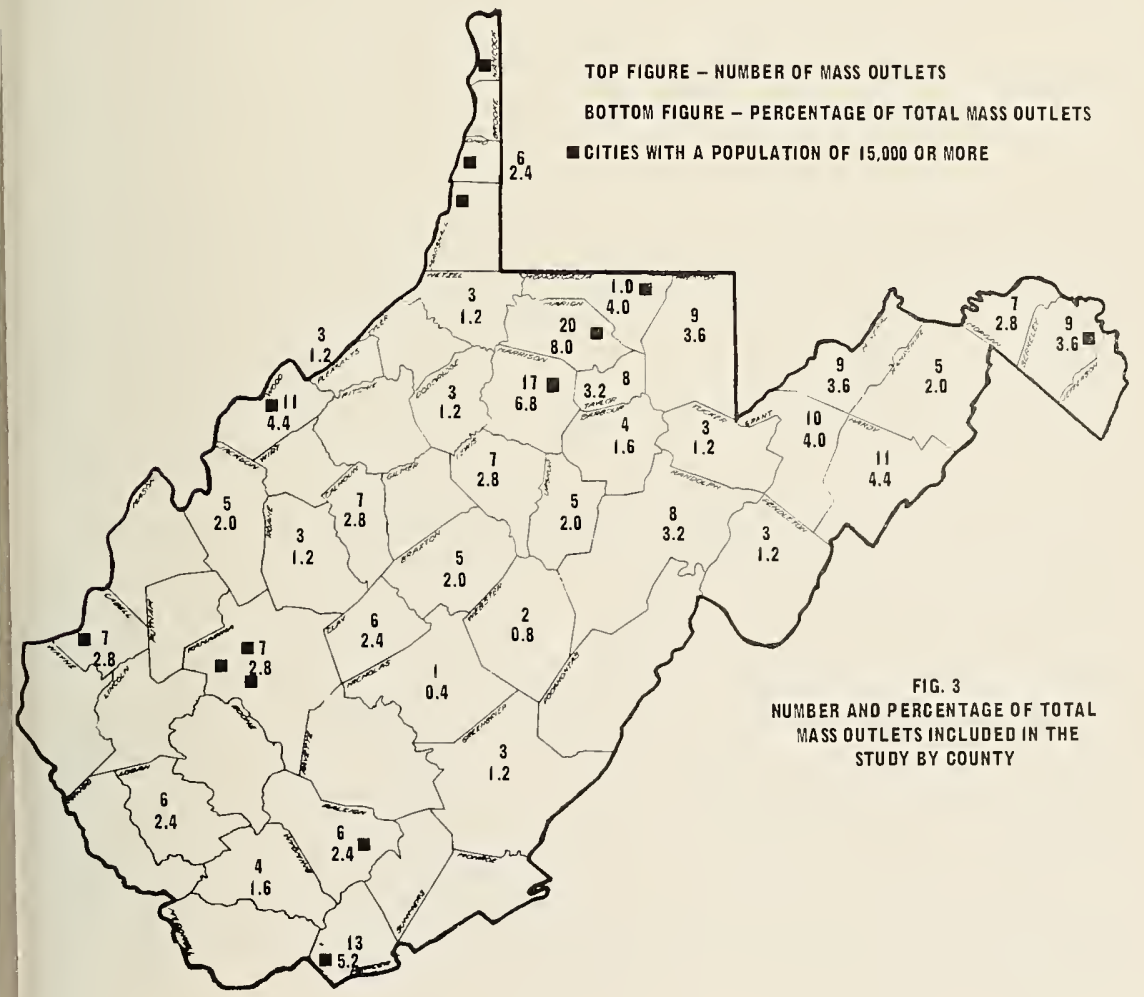




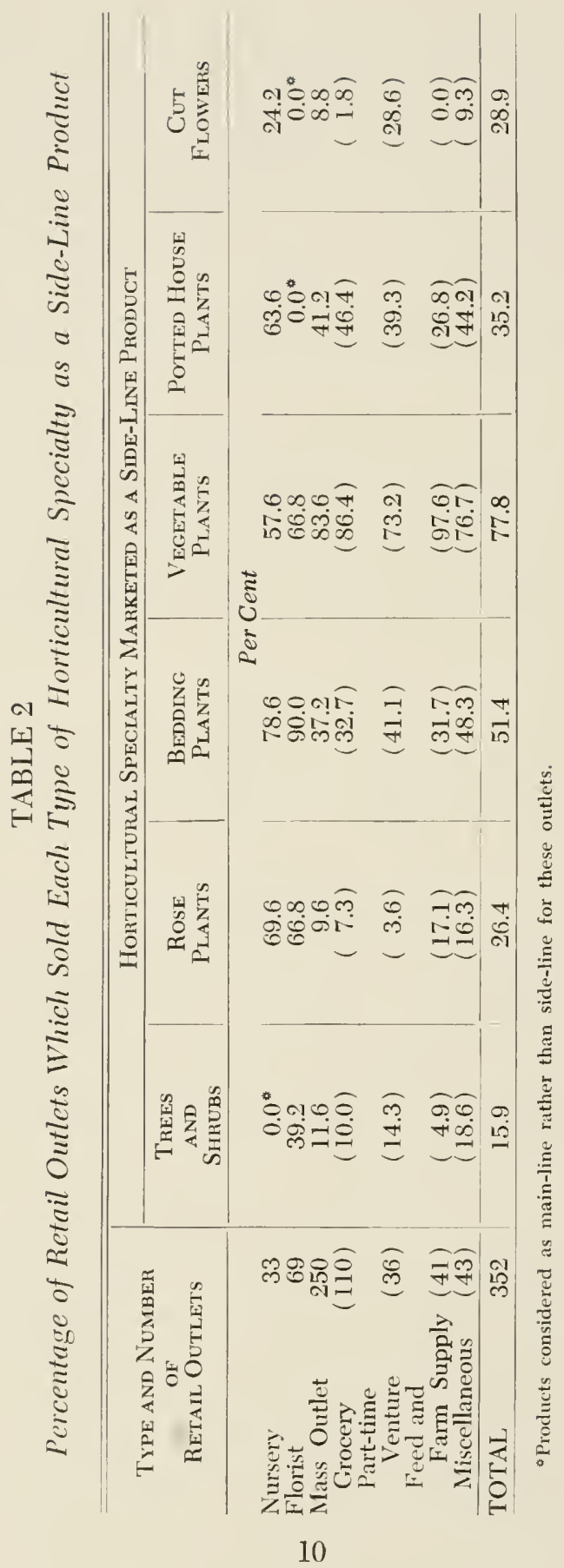


The tendency for certain types of outlets not to market particular products may be explained by several factors. Casual factors may have been domination of the market by certain types of outlets, perishability of products, equipment, knowledge, and display facilities required, and consumer demand for the products. It is expected that nurseries and florists have some control over the market for their main-line products. As a result, only a few of the other types of outlets can acquire a sufficient portion of the market to make their efforts profitable. Secondly, the rate of perishability of certain products, such as cut flowers, is rapid if the flowers are not kept under refrigeration. To avoid a financial loss due to the deterioration of some plants certain types of outlets without proper equipment tend not to market the product. Thirdly, the equipment, knowledge, and display facilities required by certain plants may influence owners or operators not to market the product. Rose plants, trees and shrubs, and cut flowers require special care, equipment and large display areas at the retail market. The cost of such equipment and care may influence the retailers not to invest in the equipment necessary to market these products. Finally, the demand for certain products may not be sufficient to provide a profit incentive for the owners or operators of the retail outlets.

The portion of total side-line product sales associated with each product represents the relative economic value of these products to retailers.

The major portion of the nurseries marketed bedding plants (see Table 2) but most of them concentrated on marketing rose plants (Table 3 ). The twenty-two nurserymen who sold rose plants indicated that these plants accounted for an average of around 45 per cent of their total sideline horticultural sales (Table 3). Twenty-four nurserymen indicated that bedding plants accounted for an average of one-third of their total ide-line horticultural sales. For seven nurseries, cut flowers accounted or half of their total side-line horticultural sales.

Fifty-nine florists indicated that bedding plants accounted for lightly more than half of their total horticultural specialty side-line sales olume. Vegetable plants made up an average side-line sales volume of 0 per cent of total side-line sales volume for forty-five florists. These lata indicate that florists marketed mostly bedding and vegetable plants.

Mass outlets concentrated on marketing vegetable plants. Vegetable lants accounted for an average of three-fourths of total side-line hortiultural sales for 206 owners or operators of mass outlets. Twenty-two lass outlets had slightly more than half of total sales of side-line hortiultural specialties from cut flowers.

Florists tend to specialize in marketing bedding plants. (One type of roduct accounted for 50 per cent or more of the total sales volume.) 
Most mass outlets seem to specialize in marketing vegetable plants and i few mass outlets specialize in marketing cut flowers. Nurserymen curry a large variety of side-line horticultural specialties. Some nurserymen market a large volume of rose plants. Production and display facilities, the extent and nature of consumer demand, the bulkiness of some products, and procurement source probably influence this tendency to specialize.

\section{Procurement Sources}

The difficulties involved in obtaining horticultural specialty products have caused considerable concem by outlets marketing these products. In the interview, a question was asked about the source from which a retail outlet obtained most of its side-line horticultural specialties (Table 4).

The major portion of the responses, 45 per cent, indicated that sideline horticultural specialties were procured from in-State sources. Some outlets, 30 per cent, grew their own products and 25 per cent of the outlets procured their products from out-of-State sources.

Nurserymen grew the major portion of their side-line horticultural specialties. This was especially true for bedding plants, vegetable plants, potted house plants, and cut flowers. Nurserymen who sold rose plants depended primarily on an out-of-State supply source.

Florists produced most of the bedding and vegetable plants sold by their retail outlets. Trees and shrubs and rose plants were procured mostly from an in-State source. Florists did not procure the major portion of any side-line horticultural specialty from an out-of-State source.

Mass outlets procured most of their trees and shrubs, bedding plants, vegetable plants, potted house plants, and cut flowers from in-State sources. The primary source of rose plants for the mass ontlets was from out-of-State. Only a small volume of the horticultural specialties was grown by the owners or operators of mass outlets.

In general, nurseries and florists produce most of their own side-line horticultural specialties for the retail market. Mass outlets depend upon other sources of supply, primarily in-State suppliers. The differences in the procurement source may be attributed to the facilities the retail outlet has for producing the products. It is expected that nurseries and florists have the facilities for producing their own products, but mass outlets probably do not have adequate production facilities. As a result, nurseries and florists can produce most of the products they sell, while mass outlets have to depend on other sources.

Many of the retail outlets did not produce trees and shrubs, and rose plants. Trees and shrubs were procured primarily from in-State suppliers, while rose plants were procured primarily from out-of-State sources. 


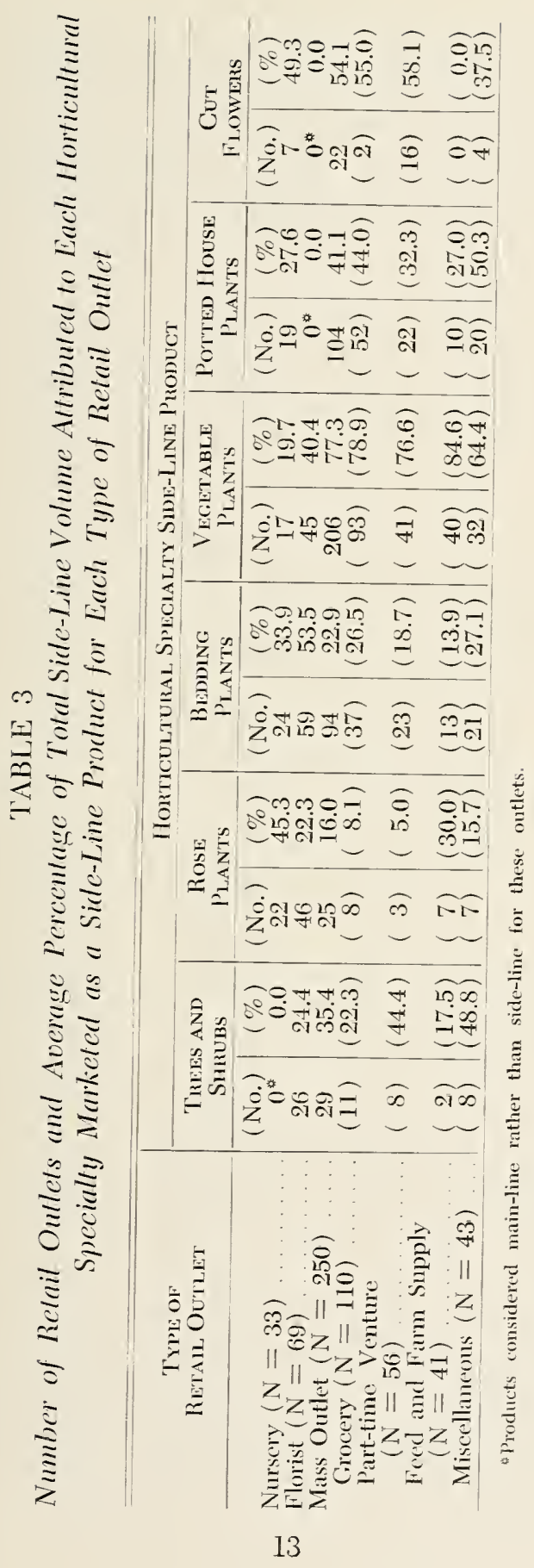


TABLE 4

Procurement Source by Type of Horticultural Specially and Type of Retail Outlet

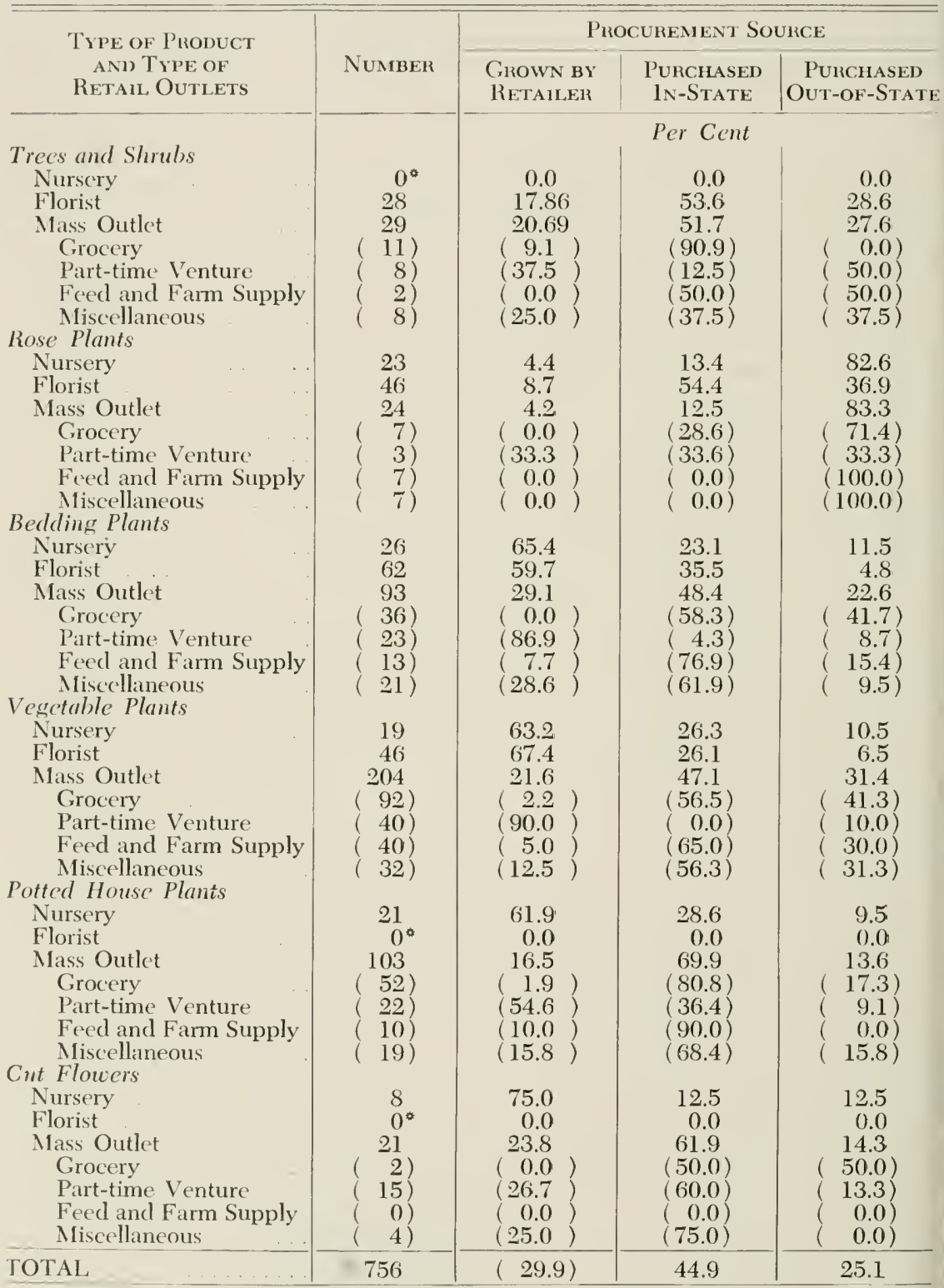

- Products considered main-line rather than side-line for these outlets. 
Trees and shrubs are relatively large, bulky plants which require special equipment, a large area per plant, and special care in the production and marketing stages. It is likely that West Virginia's climate and elevation influence retail outlets to buy this product in-State. Trees and shrubs produced out-of-State may not survive in the West Virginia climate. An in-State grower can supply retailers with a product already adapted to most of the climatic conditions and different elevations of the State.

Procurement of rose plants from out-of-State sources may be explained by two factors. First, the demand for rose plants in West Virginia may be insufficient for outlets in the State to produce rose plants in large volume. Second, the climate may make production in the State unprofitable even if insufficient demand were not a problem.

\section{Number of Months of Sales}

Horticultural specialties have a highly seasonal demand. This study attempted to determine seasonal variation in demand for side-line horticultural specialties. Analysis of the data indicated considerable variation in the number of months in which these products are sold (Table 5). The seasonal variation differed depending on the product marketed and the type of retail outlet marketing the product.

Owners or operators of all types of outlets marketing horticultural specialties as side-line products indicated that they marketed these products primarily one or two months. They also indicated that a marketing period of three or four months for some products was common. Relatively few indicated that they marketed products five to twelve months out of the year.

Trees and shrubs were marketed primarily three or four months, but the period differed depending on the type of retail outlet. Florists usually marketed trees and shrubs three or four months, while mass outlets marketed them one or two months.

Rose plants were marketed primarily three or four months, but the period differed considerably depending on the type of retail outlet. Nurseries marketed rose plants primarily five to twelve months, florists three or four months, and mass outlets one or two months.

Bedding plants were marketed by most of the outlets one or two months. Nurseries usually marketed them three or four months, but florists and mass outlets marketed them one or two months, primarily.

Vegetable plants were marketed by the majority of the outlets three or four months. Florists and mass outlets tended to market this product three or four months. Nurseries, almost exclusively, marketed vegetable plants one or two months. 
TABLE 5

Number of Outlets Marketing Each Type of Side-Line Horticultural Specialty by Number of Months Sold and Type of Retail Outlet

\begin{tabular}{|c|c|c|c|c|}
\hline \multirow{2}{*}{$\begin{array}{c}\text { TyPe of Plioduct } \\
\text { AND } \\
\text { TrPe OF OUtLet }\end{array}$} & \multicolumn{3}{|c|}{ Number of Months Sold } & \multirow{2}{*}{ TOTAL } \\
\hline & 1 or 2 & 3 or 4 & 5 to 12 & \\
\hline $\begin{array}{l}\text { Trees and Shrubs } \\
\text { Nursery ......... } \\
\text { Florist } \\
\text { Mass Outlets } \\
\text { Crocery } \\
\text { Part-time Venture } \\
\text { Feed and Farm Supply } \\
\text { Miscellaneous ....... }\end{array}$ & $\left.\begin{array}{c}0^{\circ} \\
2 \\
12 \\
(7) \\
2 \\
1 \\
2\end{array}\right)$ & $\begin{array}{c} \\
0 \\
14 \\
8 \\
\left(\begin{array}{c}4 \\
3 \\
(3) \\
0 \\
1\end{array}\right)\end{array}$ & $\left.\begin{array}{c}0 \\
11 \\
9 \\
0 \\
(3) \\
1 \\
1 \\
5\end{array}\right)$ & 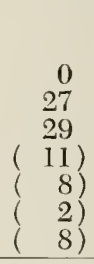 \\
\hline$\ldots \ldots \ldots$ & 14 & 22 & 20 & 56 \\
\hline $\begin{array}{l}\text { Rose Plants } \\
\text { Nursery } \\
\text { Florist } \\
\text { Mass Outlets } \\
\text { Grocery } \\
\text { Part-time Venture } \\
\text { Feed and Farm Supply } \\
\text { Miscellaneous }\end{array}$ & 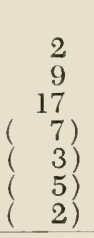 & $\begin{array}{c}10 \\
32 \\
5 \\
\left(\begin{array}{l}1 \\
0 \\
1 \\
1) \\
3\end{array}\right)\end{array}$ & $\begin{array}{c}11 \\
4 \\
1 \\
(0) \\
0) \\
1) \\
0\end{array}$ & $\begin{array}{c}23 \\
45 \\
23 \\
\left(\begin{array}{c}8 \\
3 \\
(7) \\
5\end{array}\right) \\
\end{array}$ \\
\hline Total & 28 & 47 & 16 & 91 \\
\hline $\begin{array}{l}\text { Bedding Plants } \\
\text { Nursery } \\
\text { Florist } \\
\text { Mass Outlets } \\
\text { Grocery } \\
\text { Part-time Venture } \\
\text { Feed and Farm Supply } \\
\text { Miscellaneous }\end{array}$ & 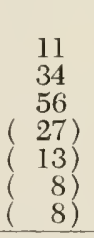 & 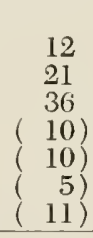 & $\begin{array}{l}3 \\
7 \\
0 \\
(0) \\
0 \\
(0) \\
(0) \\
\end{array}$ & 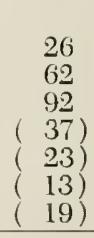 \\
\hline Total & 101 & 69 & 10 & 180 \\
\hline
\end{tabular}

Potted house plants were marketed mostly one or two months. Again, this varied with the type of retail outlet. Nurseries marketed this product primarily five to twelve months, but mass outlets tended toward one or two months of sales.

Cut flowers were mostly marketed five to twelve months. This was true both for nurseries and mass outlets.

In summary, bedding plants and potted house plants were marketed by most of the outlets one or two months. Trees and shrubs, rose plants, and vegetable plants were marketed by most of the outlets three or four months. Cut flowers was the only side-line horticultural specialty which was marketed primarily for five to twelve months.

Nurseries tended to market vegetable plants one or two months, bedding plants three or four months, and rose plants, potted house plants, and cut flowers five to twelve months. Florists had a tendency to market bedding plants one or two months, trees and shrubs, rose plants, 
TABLE 5-(Continued)

\begin{tabular}{|c|c|c|c|c|}
\hline \multirow{2}{*}{$\begin{array}{c}\text { TyPe of Product } \\
\text { AND } \\
\text { TyPE OF OUTLET }\end{array}$} & \multicolumn{3}{|c|}{ Numiber of Months Sold } & \multirow{2}{*}{ Total } \\
\hline & 1 or 2 & 3 or 4 & 5 or 12 & \\
\hline $\begin{array}{l}\text { Vegetable Plants } \\
\text { Nursery } \ldots . . . . . \\
\text { Florist . . . . . . . } \\
\text { Mass Outlets } \\
\text { Grocery } \\
\text { Part-time Venture } \\
\text { Feed and Farm Supply } \\
\text { Miscellaneous } \\
\end{array}$ & $\begin{array}{r}15 \\
19 \\
80 \\
(43) \\
16) \\
5) \\
16)\end{array}$ & $\begin{array}{c}\text { nber of } \\
3 \\
25 \\
125 \\
\left(\begin{array}{c}50 \\
24 \\
35 \\
16\end{array}\right)\end{array}$ & $\begin{array}{l}1 \\
2 \\
1 \\
\left(\begin{array}{l}0 \\
1 \\
( \\
0 \\
(0)\end{array}\right)\end{array}$ & $\begin{array}{r}19 \\
46 \\
206 \\
\left(\begin{array}{c}93 \\
41) \\
40) \\
(32)\end{array}\right. \\
\end{array}$ \\
\hline Total ......... & 114 & 153 & 4 & 271 \\
\hline $\begin{array}{l}\text { Potted House Plants } \\
\text { Nursery ........ } \\
\text { Florist . } \\
\text { Mass Outlets } \\
\text { Grocery } \\
\text { Part-time Venture } \\
\text { Feed and Farm Supply } \\
\text { Miscellaneous } \\
\end{array}$ & 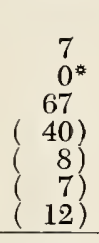 & $\begin{array}{r}3 \\
0 \\
22 \\
\left(\begin{array}{r}10 \\
6 \\
1 \\
1 \\
5\end{array}\right) \\
\end{array}$ & 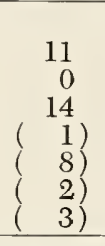 & 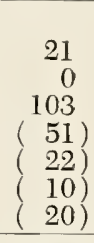 \\
\hline Total $\ldots \ldots \ldots$ & 74 & 25 & 25 & 124 \\
\hline $\begin{array}{l}\text { Jut Flowers } \\
\text { Nursery } \ldots \ldots \ldots \\
\text { Florist . . . . . . . . . . . } \\
\text { Mass Outlets } \\
\text { Grocery } \\
\text { Part-time Venture } \\
\text { Feed and Farm Supply } \\
\text { Miscellaneous . . . . . }\end{array}$ & $\begin{array}{l}\mathbf{1} \\
0^{*} \\
9 \\
1 \\
\left(\begin{array}{l}1 \\
0 \\
0 \\
2\end{array}\right) \\
\end{array}$ & $\begin{array}{l}2 \\
0 \\
1 \\
0) \\
1) \\
0) \\
0)\end{array}$ & $\begin{array}{r}5 \\
0 \\
12 \\
\left(\begin{array}{c}1 \\
9\end{array}\right) \\
0) \\
2) \\
\end{array}$ & $\begin{array}{c}8 \\
0 \\
22 \\
\left(\begin{array}{r}2 \\
16 \\
0 \\
4\end{array}\right)\end{array}$ \\
\hline Total ....... & 10 & 3 & 17 & 30 \\
\hline$\ldots \ldots \ldots \ldots$ & 341 & 319 & 92 & 752 \\
\hline
\end{tabular}

* Products considered main-line rather than side-line for these outlets.

nd vegetable plants three or four months. Mass outlets marketed trees nd shrubs, rose plants, bedding plants, and potted house plants one or wo months, primarily. Vegetable plants were marketed by most of the aass outlets for a three- or four-month period. Cut flowers was the only roduct which mass outlets marketed primarily five to twelve months.

These data suggest that regardless of the product, with the exception $\mathrm{f}$ cut flowers, the marketing period is relatively short, less than five ionths. Although certain types of retail outlets tend to market side-line orticultural specialties for different periods, considerable variation xisted in the number of months of sale.

\section{ales Value}

Horticultural specialties increased in sales value during the decade, 950 to 1960 . This study attempted to determine the sales value of hortiultural specialties marketed as side-line products by nurseries, florists, nd mass outlets. 
The average sales value of all owners or operators of retail outlets reporting side-line horticultural specialty sales value was $\$ 1,667.37$. The average sales value was $\$ 2,347.62$ for nurseries, $\$ 3,017.50$ for florists, and $\$ 1,242.48$ for mass outlets (Table 6 ). Of the mass outlet group, part-time ventures had an average sales value of $\$ 2,221.29$, which was considerably higher than the other types of mass outlets.

Considerable variation occurred in the average sales value for each type of retail outlet. The distribution of the outlets in the various sales value categories also varied widely (Table 6 ). For example, there were six nurseries in the $\$ 1-\$ 400$ category and four in the $\$ 4,100$ and over category. A statistical test was used to determine if this distribution was significantly different from a random distribution. The test was highly significant indicating that factors other than random variation influenced the distribution.

These data indicate considerable variation in the sales value of horticultural specialties marketed as side-line products. The variation depended on the type of retail outlet. These data also indicate that mass outlets, especially part-time ventures, have sufficient sales value to be considered as important competitors in the market. This competitiveness of mass outlets should be considered by nurseries and will influence florists in pricing and establishing policies of horticultural specialties marketed as side-line products.

\section{Consignment Sales}

Owners and operators of nurseries, and florists, have expressed concern about consignment sales of horticultural specialties marketed as side-line products by mass outlets. Nurserymen and florists believed that the competitive position of the mass outlets was improved by consignment selling of horticultural specialty products.

Only 15 per cent of the 352 outlets sold side-line horticultural specialties on a consignment basis (Table 7 ). One nursery and one florist sold side-line horticultural specialties on consignment. Only a fourth of the mass outlets sold products on a consignment sales basis.

The average sales value of consigned side-line horticultural specialties was less than $\$ 100$ each for the florist and for the nursery, and $\$ 484.85$ for the mass outlet.

These data indicate that only a few retail outlets use consignment selling for horticultural specialties marketed as side-line products. Of the outlets that do use consignment selling, the sales value is low and the suppliers have control of this sales method.

Consignment sales of side-line horticultural specialties play only a minor role in the over-all marketing of side-line horticultural specialty products. 


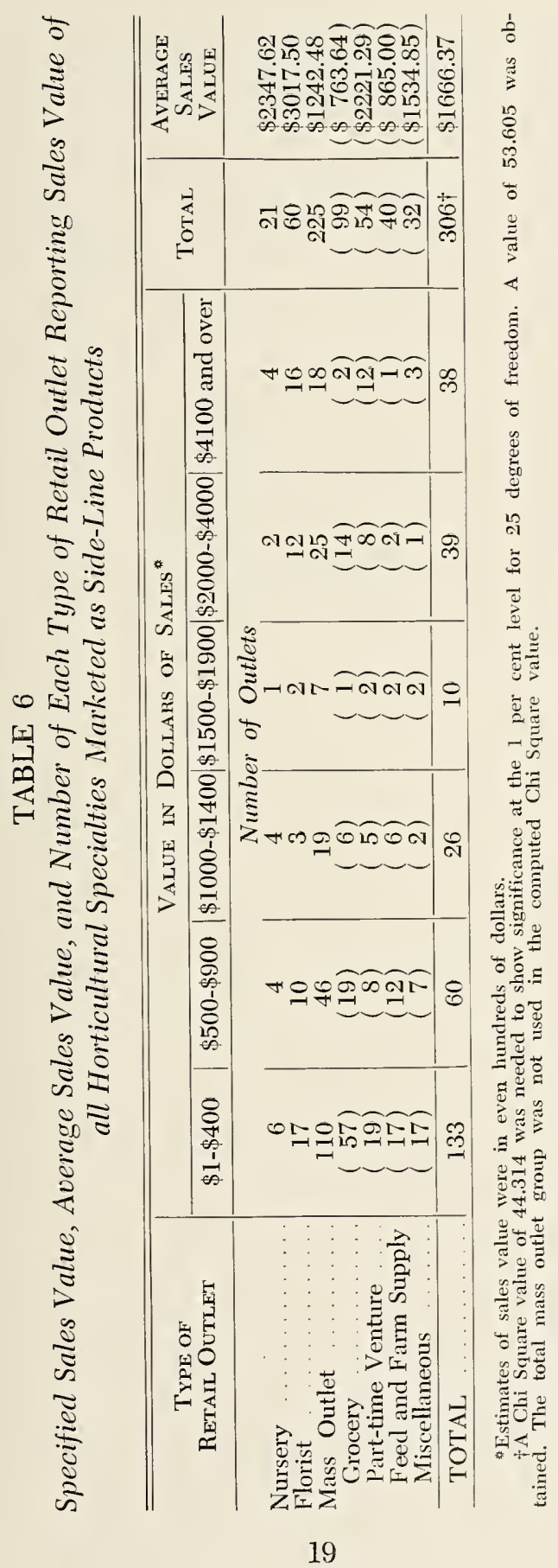


TABLE 7

Type, Number, and Percentage of Retail Outlets W'hich did and did not Sell Horticultural Specialties as Side-Line Products on a Consignment Sales Basis

\begin{tabular}{|c|c|c|c|c|}
\hline \multirow[b]{2}{*}{$\begin{array}{l}\text { TYPE OF } \\
\text { RetAll OUTLET } \\
\text { Nursery }(\mathrm{N}=33) \\
\text { Florist }(\mathrm{N}=69) \\
\text { Mass Outlet }(\mathrm{N}=250) \\
\text { Grocery }(\mathrm{N}=1 \mathrm{I} 0) \\
\text { Part-time Venture } \\
(\mathrm{N}=56) \\
\text { Feed and Farm Supply } \\
(\mathrm{N}=41) \\
\text { Miscellaneous }(\mathrm{N}=43)\end{array}$} & \multicolumn{2}{|c|}{ SELling bi CoNigingeNT } & \multicolumn{2}{|c|}{$\begin{array}{c}\text { Кот Selling } \\
\text { By. Consignifent }\end{array}$} \\
\hline & 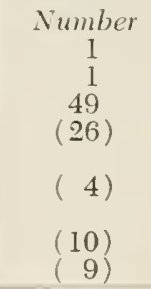 & $\begin{array}{c}\text { Per Cent } \\
3.0 \\
1.4 \\
19.6 \\
(23.6) \\
(7.1) \\
(24.4) \\
(20.9)\end{array}$ & $\begin{array}{c}\text { Number } \\
32 \\
68 \\
201 \\
\left(\begin{array}{c}84 \\
)\end{array}\right. \\
\left(\begin{array}{c}52 \\
\end{array}\right) \\
\left(\begin{array}{c}31 \\
(34)\end{array}\right)\end{array}$ & $\begin{array}{c}\text { Per Cent } \\
97.0 \\
98.6 \\
80.4 \\
(76.4) \\
(92.9) \\
(75.6) \\
(79.1)\end{array}$ \\
\hline TOTAL $(\Lambda=352)$ & 51 & 14.5 & 301 & 85.5 \\
\hline
\end{tabular}


APPENDIX 


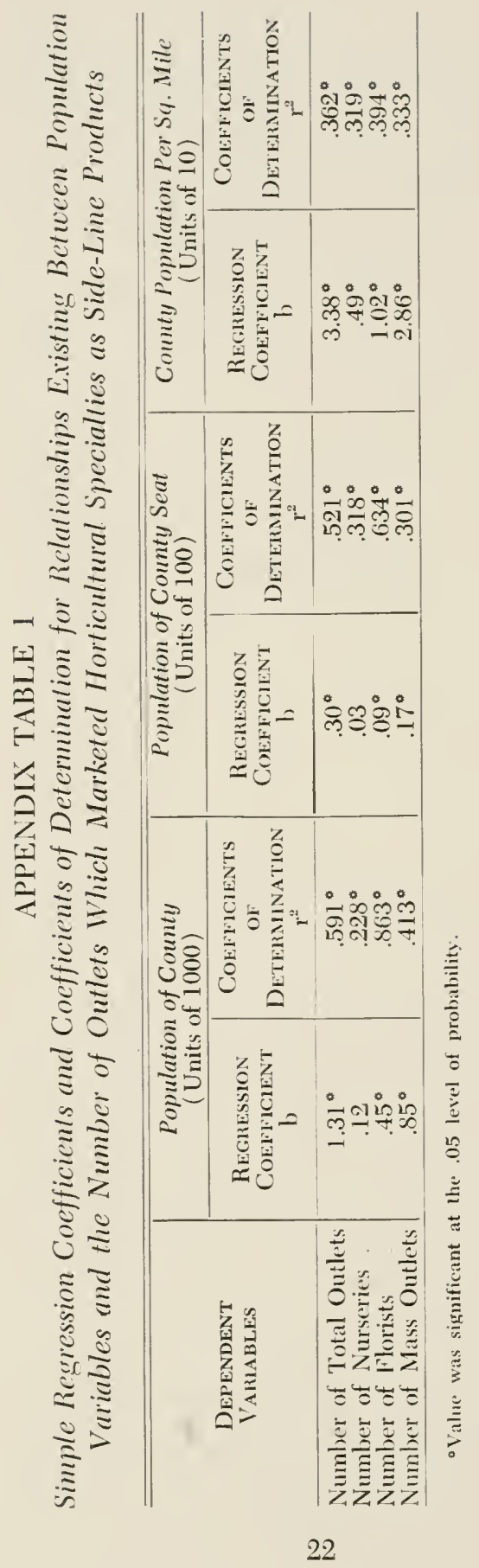




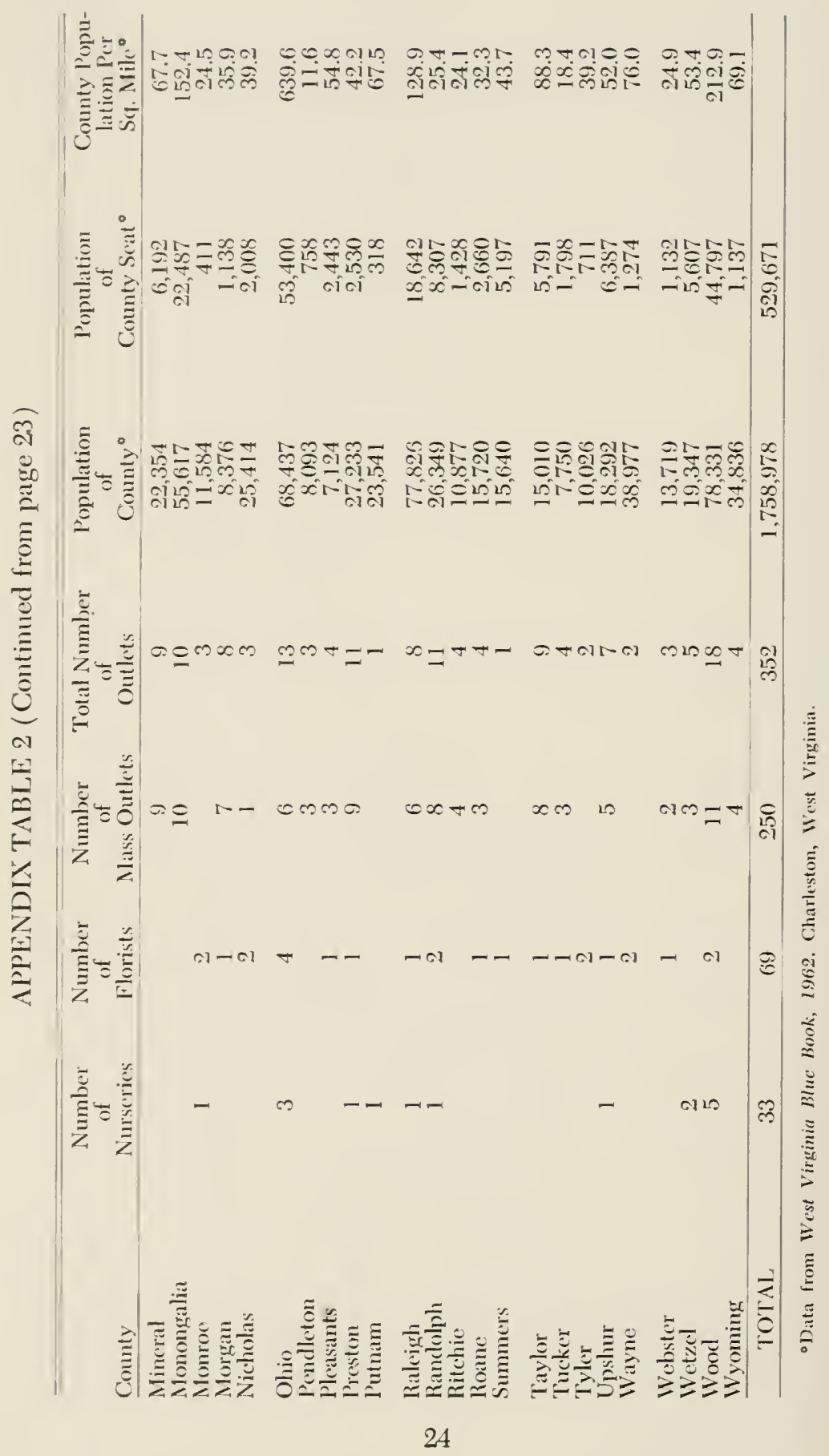



mingen

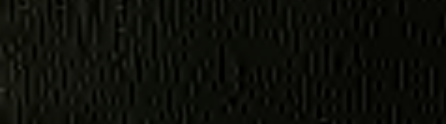

Q)

(1.5)

iing

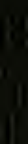

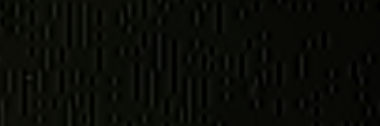

(1)

$\operatorname{lin}_{10} 13$

$\operatorname{lig} 6$

D.

III

ing

$\lim _{40}$

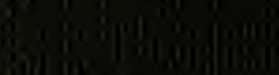

(initis

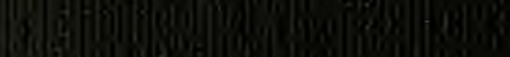

a 